\title{
PENGARUH IKLIM KOMUNIKASI ORGANISASI DAN SISTEM PENGHARGAAN TERHADAP KINERJA KARYAWAN
}

Hardikna Agasta

FISIP Universitas Airlangga, Surabaya, Indonesia, Email: diknaagasta@gmail.com

\begin{tabular}{|c|}
\hline \hline \\
\\
\hline Histori Artikel \\
Submitted: \\
1 Juli 2019 \\
Reviewed: \\
1 September 2019 \\
Accepted: \\
7 September 2019 \\
Published: \\
11 Oktober 2019 \\
\hline
\end{tabular}

\begin{abstract}
ABSTRAK
Dengan mengetahui bahwa iklim komunikasi organisasi dan sistem penghargaan berpengaruh terhadap kinerja karyawan, organisasi dapat memperbaiki komunikasi dan sistem penghargaan yang sesuai sehingga dapat meningkatkan kinerja dari karyawan. Oleh karena itulah, fokus penelitian ini adalah untuk menjelaskan pengaruh iklim komunikasi organisasi dan sistem penghargaan terhadap kinerja karyawan Hotel Best Western Papilio Surabaya. Teori yang digunakan pada penelitian ini adalah teori komunikasi internal organisasi, iklim komunikasi organisasi, sistem penghargaan, dan kinerja. Penelitian ini menggunakan pendekatan kuantitatif eksplanatif dengan menggunakan metode survey. Survey dilakukan dengan menyebar kuesioner kepada 104 orang karyawan Hotel
\end{abstract} Best Western Papilio Surabaya. Hasil dari penelitian ini menunjukkan bahwa secara simultan iklim komunikasi dan sistem penghargaan memiliki pengaruh terhadap kinerja karyawan Hotel Best Western Papilio Surabaya sebesar 30,2\% dan sisanya yaitu 69,8\% dipengaruhi oleh faktor lain yang tidak diteliti dalam penelitian ini.

Kata kunci: komunikasi organisasi, iklim komunikasi organisasi, sistem penghargaan, kinerja.

\section{THE INFLUENCE OF ORGANIZATIONAL COMMUNICATION CLIMATE AND THE AWARD SYSTEM FOR EMPLOYEE PERFORMANCE}

\begin{abstract}
By knowing that the organizational communication climate and reward system affect employee performance, organizations can improve communication and reward systems accordingly so as to improve the performance of employees. Therefore, the focus of this research is to explain the influence of the organizational communication climate and the system of rewards for the performance of employees of the Best Western Papilio Hotel Surabaya.The theory used in this study is the organization's internal communication theory, organizational communication climate, reward system, and performance. This study uses an explanative quantitative approach using the survey method. The survey was conducted by distributing questionnaires to 104 employees of the Best Western Papilio Hotel Surabaya. The results of this study show that simultaneously the communication climate and reward system have an influence on the performance of employees of the Best Western Papilio Hotel in Surabaya by $30.2 \%$ and the remaining $69.8 \%$ influenced by other factors not examined in this study.
\end{abstract}

Keyword: organization communication, organizational communication climate, rewards system, performances 


\section{PENDAHULUAN}

Penelitian ini dilakukan untuk mengetahui pengaruh iklim komunikasi organisasi dan sistem penghargaan terhadap kinerja karyawan. Iklim komunikasi organisasi terbagi menjadi dua kategori yaitu iklim komunikasi suportif yang terdiri dari aspek deskriptif, problem orientation, spontanitas, empati, equality, dan provesionalism, serta iklim komunikasi defensif yang terdiri dari aspek evaluasi, kontrol, strategi, netralitas, superioritas, dan kepastian (Gibb, 1961). Melalui penelitian ini, akan dijelaskan bahwa kedua belas aspek iklim komunikasi tersebut yang berhubungan dengan praktik- praktik komunikasi dan juga sistem penghargaan yang terdiri dari unsur ekstrinsik dan instrinsik, memiliki pengaruh terhadap kinerja karyawan di Hotel Best Western Papilio Surabaya. Peneliti memilih fenomena tersebut karena dalam sebuah organisasi iklim komunikasi memiliki peran krusial pada kesuksesan dan kinerja organisasi (Pace dan Faules, 2015). Begitu pula dengan sistem penghargaan yang juga merupakan salah satu kunci keberhasilan organisasi. Keberhasilan organisasi dapat dicapai jika kinerja dari anggota organisasi berjalan baik pula. Dengan mengetahui bahwa iklim komunikasi organisasi dan sistem penghargaan berpengaruh terhadap kinerja karyawan, organisasi dapat memperbaiki komunikasi dan sistem penghargaan yang sesuai sehingga dapat meningkatkan kinerja dari karyawan (Bustamama et al., 2014).

Keterhubungan antara iklim komunikasi organisasi dan sistem penghargaan dengan kinerja karyawan akan dibahas dalam penelitian ini dengan menggunakan objek penelitian yaitu Hotel Best Western Papilio
Surabaya. Hotel Best Western Papilio berdiri pada 9 Agustus 2015 dan dalam waktu kurang lebih satu tahun telah mendapatkan sertifikasi hotel bintang 4 dari Lembaga Sertifikasi Usaha Pariwisata. Selain itu pula, Best Western Papilio mendapatkan skor tinggi pada aspek manajemen, pelayanan dan produk hotel yang ditetapkan oleh Kementerian Pariwisata. Director of National Hospitality Dr. Bambang Hermantu, menyatakan bahwa Hotel Best Western Papilio merupakan hotel bintang 4 terbaik di Surabaya bahkan di Indonesia (Dailyhotels.id article, 2016). Pada 2017, Best Western Papilio mendapat penghargaan Gold Circle Award dari agoda, yang merupakan penghargaan tentang kualitas hotel. Agoda memberikan penghargaan tersebut hanya $0.5 \%$ atau dibawah 100 dari total hotel yang ada di Indonesia. Berdasarkan hasil wawancara pra penelitian pada 13 April 2019 dengan Bu Intan, selaku Marcomm Hotel Best Western Papilio menyatakan bahwa, seluruh penghargaan tersebut tidak lain merupakan hasil kinerja dari seluruh karyawan yang mampu bekerjasama untuk menghasilkan kinerja yang baik. Kinerja yang baik dapat dihasilkan dari komunikasi yang baik pula antar sesama karyawan saat bekerja (Wibowo, 2007).

Peran karyawan dalam hotel menjadi penting karena kinerja dari karyawan hotel akan mempengaruhi kesan, kepuasan, dan loyalitas pelanggan terhadap organisasi (Bustamam, 2014). Kinerja anggota organisasi menjadi penentu bagaimana organisasi tersebut akan berjalan. Bila kinerja anggota organisasi baik maka kinerja perusahaan juga baik (Prawirosentono, 1999). Stern dalam Mangkunegara (2010) menjabarkan bahwa terdapat dua faktor yang 
dapat menjadi penentu dalam kinerja individu yaitu faktor individu dan faktor lingkungan kerja organisasi. Faktor individu disini termasuk kemampuan, kecerdasan, emosi, pengetahuan, motivasi, dan konsentrasi. Sedangkan faktor lingkungan kerja yang dimaksud adalah target kerja, pola komunikasi kerja efektif, hubungan kerja harmonis, peluang berkarier, fasilitas kerja, pemimpin yang memberdayakan, dan bagaimana pemimpin memberikan penghargaan (Wibowo, 2007). Dari pernyataan tersebut dapat disimpulkan bahwa beberapa faktor dapat mempengaruhi kinerja dari karyawan, seperti komunikasi dan penghargaan. Sehingga pada penelitian ini pun, peneliti akan menjelaskan pengaruh dari iklim komunikasi dan sistem penghargaan terhadap kinerja karyawan.

Iklim komunikasi merupakan hasil interaksi anggota organisasi terhadap segala sesuatu yang terjadi dalam organisasi. Melalui komunikasi anggota dapat satu sama lain membantu beradaptasi dan saling mendukung dalam menyesuaikan dengan perubahan tersebut (Harjana, 2007). Oleh karena itu, dengan menjaga iklim komunikasi tetap kondusif akan membantu organisasi menjaga kinerja karyawannya tetap baik dalam mencapai tujuan organisasi. Iklim komunikasi yang suportif menunjukkan adanya keterbukaan komunikasi antara atasan dan bawahan. Anggota dalam organisasi baik atasan maupun bawahan saling berkomunikasi mengenai tugasnya dan tidak ada rasa segan atau takut, sehingga tidak ada kesalahpahaman dan pekerjaan berjalan baik. Jika komunikasi berjalan lancar antara atasan dan bawahan, maka pekerjaan juga dapat terselesaikan dengan baik.

Selain iklim komunikasi organisasi yang dapat mempengaruhi kinerja dari karyawan, sistem penghargaan yang diterapkan dalam organisasi atau perusahaan juga mempengaruhi kinerja karyawan. Berdasarkan Fay and Thompson (2001) menyatakan bahwa, "rewards systems have a critical role in determining the organization's ability to attract high potential employees and to retain high performing employees to achieve greater levels of quality and performance." Sistem penghargaan (reward system) merupakan sistem organisasi yang berhubungan tipe pemilihan penghargaan yang digunakan oleh organisasi (Byars \& Rue, 2000). Menurut Bustamama, Tenga, \& Abdullah (2014) menyatakan bahwa implementasi dari sistem penghargaan dalam organisasi merupakan kunci kinerja organisasi yang berpengaruh besar pada kinerja dan motivasi karyawan saat bekerja. Keberadaan sistem penghargaan ini memenuhi kebutuhan dan keinginan dari anggota organisasi.

\section{LITERATUR REVIEW}

\section{Komunikasi Internal Organisasi Hotel}

Komunikasi dalam organisasi dilakukan secara ekternal dan internal. Secara eksternal komunikasi dilakukan dengan pihak luar organisasi. Sedangkan, secara internal komunikasi terjadi antar orang- orang yang ada dalam organisasi. Komunikasi internal merupakan pertukaran persepsi atau gagasan di antara para karyawan dalam departemendepartemen perusahaan dengan struktur lengkap secara horisontal maupun vertikal di dalam perusahaan (Bartono \& Ruffino, 2007). Komunikasi internal berperan penting dalam mengatur dan mengkoordinasi semua aktivitas yang terjadi dalam organisasi sesuai dengan operasional perusahaan. Struktur komunikasi internal terdiri dari dua macam yaitu komunikasi formal dan juga komunikasi informal. Komunikasi formal 
adalah komunikasi menurut struktur organisasi yaitu komunikasi ke bawah (downward communication), komunikasi ke atas (upward communication) dan komunikasi horisontal (Mulyana, 2007). Komunikasi informal terjadi tidak bergantung pada struktur organisasi (Mulyana, 2007). Komunikasi informal dilakukan pada rekan sesama karyawan tanpa melihat struktur hierarki. Komunikasi yang terjadi bersifat lebih personal. Seperti yang ditegaskan oleh Sanford dalam Liliweri (2004, pp. 73- 74), bahwa "komunikasi informal berfungsi untuk memenuhi kebutuhan sosial, kontrol sosial, dan jawaban berbagai persoalan".

Komunikasi internal yang terjadi pada hotel berlaku sama dengan organisasi lain di mana juga terjadi komunikasi vertikal dan horisontal serta formal dan informal (Bartono \& Ruffino, 2007). Menurut Purwanto (2006) komunikasi tersebut dapat disampaikan melalui dua saluran yaitu saluran lisan (oral) dan saluran tertulis (written). Misalkan, komunikasi saluran lisan antara atasan dan bawahan yang melakukan meeting secara personal dengan manager setiap minggu secara bergantian atau secara tertulis dengan memo atau laporan untuk menyampaikan keluh kesah ataupun ide- ide yang berkaitan dengan pengembangan organisasi.

\section{Iklim Komunikasi Organisasi}

Iklim komunikasi sendiri menurut Pace dan Faules (2015) "merupakan gabungan dari persepsi- persepsi anggota organisasi (suatu evaluasi makro) mengenai peristiwa komunikasi, perilaku manusia, respon karyawan terhadap karyawan lainnya, harapan- harapan, konflik- konflik antar persona, dan kesempatan bagi pertumbuhan dalam organisasi tersebut". Iklim komunikasi mengambarkan bagaimana suasana atau jalannya komunikasi dalam suatu organisasi.
Jack Gibb (1961) mengidentifikasi iklim komunikasi suatu organisasi itu terbagi menjadi dua yaitu iklim komunikasi organisasi yang suportif dan iklim komunikasi organisasi yang defensif.

Berdasarkan Gibb (1961), tanda- tanda sebuah organisasi memiliki iklim suportif adalah bersifat deskriptif, problem orientation, spontanitas, empati, equality, dan provesionalism. Menurut Forward et al. (2011), deskripsi dapat dilihat dari cara anggota organisasi menyampaikan informasi atau menanggapi suatu hal, yaitu disampaikan secara objektif tidak mengintimidasi atau emosional. Kemudian problem orientation berarti komunikasi dengan anggota bertujuan untuk menyelesaikan masalah dan mengajak bekerjasama (Gibb, 1961). Ketiga yaitu spontanitas, pembicaraan dilakukan secara spontan dan terus terang. Empati berarti rasa peduli dan pengertian terhadap sesama anggota. Selanjutnya, kesetaraan (equality) yang berarti bahwa anggota dalam organisasi dianggap setara dan memiliki hak yang sama. Aspek terakhir yaitu provisionalism berarti bersikap secara profesional dalam melakukan segala hal dengan terbuka pada segala kritik dan saran (Harjana, 2007).

Sedangkan iklim yang defensif juga dijelaskan oleh Gibb (1961) memiliki enam aspek ciri- ciri yaitu evaluasi, kontrol, strategi, netralitas, superioritas, dan kepastian. Evaluasi (evaluation) berarti komunikasi yang berlangsung penuh dengan intimidasi, kritikan, celaan atau kecaman, atau bisa dikatakan bersifat secara subjektif dan emosional. Kontrol (control) yaitu adanya pengendalian, manipulasi, desakan, atau paksaan untuk mengubah pandangan sesuatu. Kemudian aspek berikutnya yaitu strategi, yang berarti banyak praktik- praktik pengelabuan, siasat, untuk menguntungkan 
satu pihak. Gibb (1961) menyatakan bahwa pada aspek netralitas ini anggota organisasi tidak menganggap penting keberadaan orang lain. Selanjutnya yaitu superioritas, berarti sikap dan tindakan atasan yang mengandalkan kekuasaan. Terakhir, yaitu aspek kepastian (certainty) di mana segala keputusan sudah pasti dan tidak dapat diubah satu pihak, sehingga tidak ada perbaikan atau penyampaian ide dari anggota lain.

\section{Sistem Penghargaan}

Sistem penghargaan (reward system) merupakan sistem organisasi yang berhubungan dengan tipe pemilihan penghargaan yang digunakan oleh organisasi (Byars \& Rue, 2000). Jenis penghargaan sendiri terbagi menjadi dua, yaitu penghargaan finansial (ekstrinsik) dan penghargaan non finansial (intrinsik) (Armstrong \& Murlis, 2007). Penghargaan berbentuk finansial (ektrinsik) terdiri dari upah/ gaji, bonus/komisi, promosi dan benefit (tunjangan). Untuk penghargaan non finansial (intrinsik) merupakan penghargaan yang tidak berbentuk material dan lebih ke psikologis dimana para karyawan berharap untuk mendapatkannya saat bekerja (Mehmood et al., 2013). Duncan Brown \& Michael Armstrong dalam Armstrong \& Murlis (2007) membuat suatu kategori penghargaan intrinsik sebagai berikut:

a. Inspiration \& values: Penghargaan yang didapatkan berupa pengakuan dari atasan, atasan yang membimbing, serta couching \& mentoring.

b. Quality of works: Penghargaan berupa feedback \& apresiasi kinerja, serta kesempatan karyawan untuk menggunakan inisiatifnya atau ide dalam memutuskan sesuatu.

c. Interest \& choices: Penghargaan berupa peningkatan karir, kesempatan untuk belajar hal baru, kesempatan untuk meningkatkan kompetensi.

d. Environment: Penghargaan berupa lingkungan yang mendukung seperti lingkungan social, alat dan perlengkapan untuk job training.

\section{Kinerja}

Kinerja sendiri merupakan hasil kerja yang dicapai oleh karyawan dalam melaksanakan tugasnya baik secara kuantitas dan kualitas sesuai dengan tanggung jawab yang diberikan (Mangkunegara, 2000). Kinerja karyawan tidak selamanya berlangsung baik pasti selalu ada penurunan. Oleh karena itu, organisasi harus memantau kinerja dengan melakukan penilaian kinerja dari karyawan agar mengetahui apa yang menjadi kekurangan organisasi sehingga kinerja pekerja menurun. Mark Zweig dalam Prawirosentono (1999) menyebutkan bahwa, "penilaian kinerja adalah proses penilaian hasil kerja yang akan digunakan oleh pihak manajemen untuk memberi informasi kepada para karyawan secara individual, tentang mutu hasil pekerjaannya dipandang dari sudut pandang kepentingan perusahaan."

Penilaian kinerja dapat dilakukan melalui beberapa indikator, Wibowo (2007) telah merangkum beberapa indikator yang dapat melihat atau mengukur kinerja dari keryawan, seperti sebagai berikut:

a. Produktivitas, yaitu output yang dihasilkan oleh karyawan apakah dapat menyelesaikan tugas sesuai dengan waktu yang telah ditentukan.

b. Kualitas kerja, yaitu hasil kerja dari karyawan sudah sesuai dengan prosedur dan hasilnya baik tanpa cacat atau kesalahan.

c. Pengetahuan tentang pekerjaan, yaitu tingkat pengetahuan yang terkait dengan tugas yang akan dikerjakan 
d. Adaptasi dan fleksibilitas, yaitu tingkat kemampuan dan kecepatan dalam menerima instruksi kerja dan menyesuaikan dengan cara kerja serta situasi kerja yang ada.

e. Inisiatif \& pemecahan masalah, yaitu tingkat inisiatif selama melaksanakan tugas pekerjaan khususnya dalam hal penanganan masalah-masalah yang timbul.

f. Kooperatif, yaitu menunjukkan tingkat kemampuan kerjasama karyawan dalam menyelesaikan pekerjaan.

g. Pertanggungjawaban, yaitu seberapa tepat waktu karyawan datang setiap harinya, mengikuti aturan, dan kemandirian dalam mengerjakan tugas.

h. Kemampuan berkomunikasi, yaitu kemampuan karyawan untuk berkomunikasi dengan sesama karyawan, atasan, ataupun pihak luar organisasi.

\section{Hipotesis}

Hipotesis Nol (H0):

Tidak terdapat pengaruh iklim komunikasi organisasi dan sistem penghargaan terhadap kinerja karyawan di Hotel Best Western Papilio Surabaya.

Hipotesis Alternatif

(H1): Terdapat pengaruh iklim komunikasi organisasi terhadap kinerja pada karyawan di Hotel Best Western Papilio Surabaya, bahwa organisasi yang memiliki iklim komunikasi suportif cenderung tinggi kinerja karyawannya. Sedangkan organisasi yang memiliki iklim komunikasi defensif cenderung rendah kinerja karyawannya.

(H2): Terdapat pengaruh sistem penghargaan dengan kinerja karyawan di Hotel Best Western Papilio Surabaya, bahwa semakin banyak jenis penghargaan yang diterima semakin tinggi kinerja karyawan.

(H3): Terdapat pengaruh iklim komunikasi organisasi dan sistem penghargaan secara bersama-sama (simultan) terhadap kinerja karyawan.

\section{METODE}

Penelitian ini menggunakan pendekatan kuantitatif eksplanatif. Penelitian ini menggunakan metode penelitian survey. Survey dilakukan dengan menyebarkan kuesioner kepada karyawan Hotel Best Western Papilio Surabaya. Populasi penelitian merupakan karyawan Hotel Best Western Papilio yang terdiri dari 139 orang yang terbagi dalam 9 departemen. Dengan menggunakan metode proportionate stratified random sampling dan perhitungan menggunakan rumus slovin, didapat sampel penelitian sebesar 104 orang.

Instrumen penelitian menggunakan Instrumen penelitian yang digunakan pada penelitian ini adalah kuesioner. Dimana dalam kuesioner tersebut terbagi menjadi tiga bagian pertanyaan yaitu iklim komunikasi organisasi, sistem penghargaan, dan kinerja karyawan. Pertanyaan mengenai iklim komunikasi didasarkan pada Communication Climate Inventory yang dioperasionalisasikan oleh Costigan \& Schmeidler dari teori iklim komunikasi organisasi milik Gibb (Forward, et.al, 2011). Sedangkan untuk pertanyaan mengenai sistem penghargaan didasarkan pada teori pembagian sistem penghargaan oleh (Armstrong \& Murlis, 2007). Terakhir, untuk pertanyaan mengenai kinerja karyawan didasarkan pada teori penilaian kinerja oleh Wibowo (2007). Skala Likert berhubungan dengan sikap seseorang terhadap sesuatu. Setiap pertanyaan mempunyai empat alternatif jawaban yaitu "sangat setuju", "setuju", "tidak setuju", dan "sangat tidak setuju". 
Tabel 1 Operasionalisasi konsep

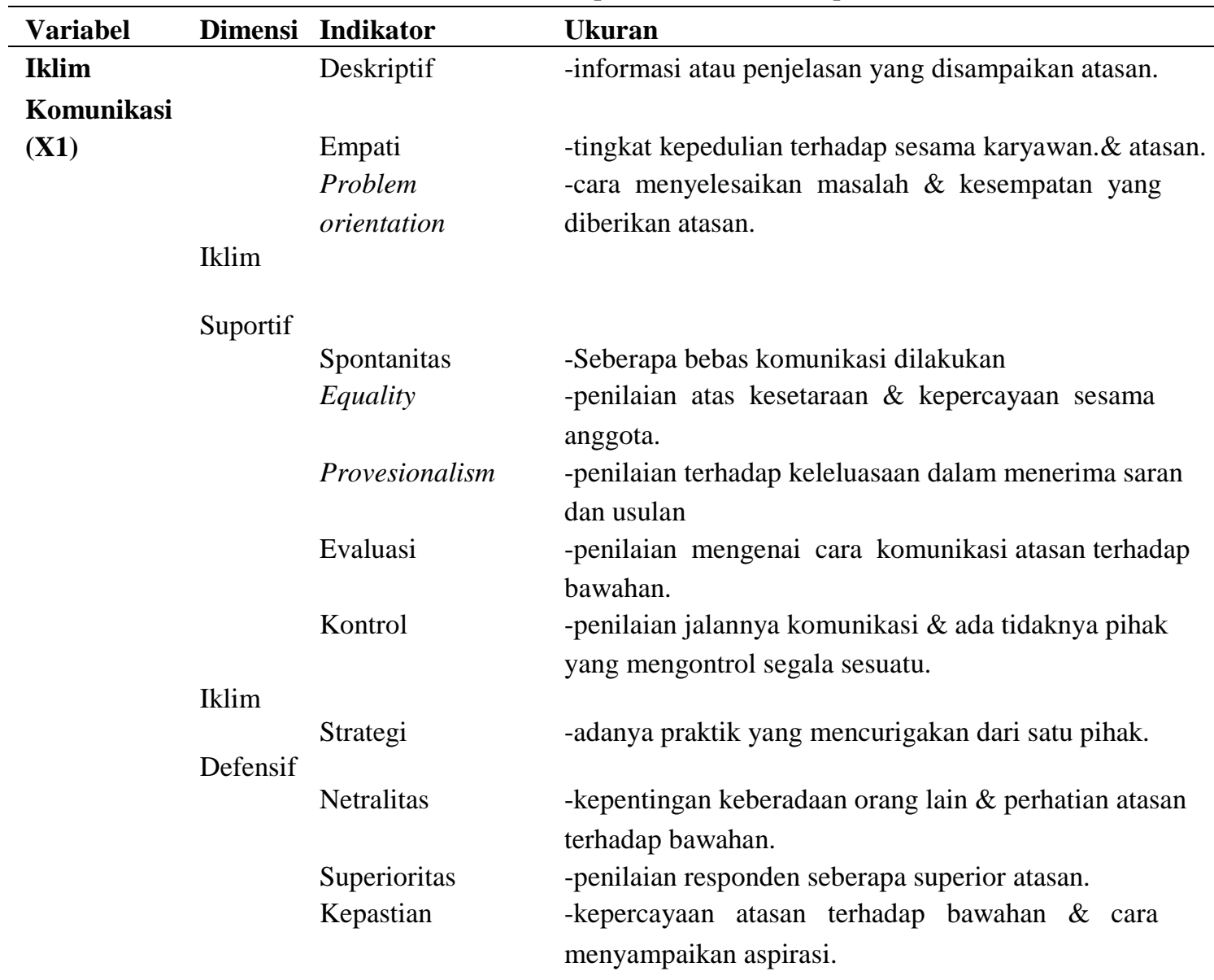

Sistem

Penghargaan Pengharg Bonus/komi

(X2)

$\begin{array}{ll}\text { aan } & \text { Promosi } \\ \text { Ektrinsik } & \text { Benefit } \\ \text { Pengharg } & \text { Inspiration } \\ \text { aan } & \text { values } \\ \text { intrinsik } & \text { Quality of works } \\ & \text { Interest } \\ & \text { choices } \\ & \text { Environment } \\ & \text { Produktivitas }\end{array}$

Kualitas kerja

Pengetahuan

tentang

pekerjaan

Adaptasi

fleksibilitas

Kinerja (Y)
Inisiatif

Kooperatif

Pertanggungjaw

aban -penilaian responden terhadap gaji yang mereka terima. -penilaian responden tentang bonus yang diberikan. -penilaian responden mengenai promosi. -penilaian terhadap tunjangan \& sistem libur serta cuti.

\& -penilaian terhadap pujian, bimbingan, arahan, \& apresiasi atasan.

-penilaian responden tentang feedback dari atasan.

\& -kesempatan yang diberikan perusahaan untuk meningkatkan kompetensi \& tantangan pekerjaan. -rekan lingkungan bekerja \& fasilitas perusahaan. -output yang dihasilkan \& kemampuan karyawan dalam menentukan prioritas.

-kualitas kerja yang dilakukan. -pengetahuan tugas atau pekerjaan \& kemampuan karyawan memanfaatkan sesuatu dengan benar.

\& -adaptasi karyawan \& kerja karyawan dibawah tekanan. 
Kemampuan -kemampuan berkomunikasi.

berkomunikasi

Analisis data dilakukan dengan bantuan program SPSS for windows ver.25. Dalam melakukan analisis terdapat beberapa tahapan yaitu uji asumsi klasik (linieritas, normalitas, heteroskedastisitas, multikolinieritas), uji korelasi, uji hipotesis (Uji F \& Uji T), uji regresi linier sederhana, uji regresi linier berganda, dan koefisen determinasi $\left(\mathrm{R}^{2}\right)$.

\section{HASIL DAN PEMBAHASAN}

Sebelum menjabarkan tentang hasil penelitian, melalui uji validitas dan reliabilitas instrumen penelitian berupa kuesioner telah dinyatakan valid dan reliabel. Kemudian uji asumsi klasik yang terdiri dari uji linieritas, normalitas, heteroskedastisitas, dan multikolinieritas dinyatakan memenuhi syarat untuk bisa melakukan uji regresi linier. Berikut merupakan penjabaran hasil penelitian.

\section{Iklim Komunikasi Organisasi}

Berdasarkan tabel 2 dapat dilihat bahwa hasil akumulasi skor dari jawaban pernyataan iklim komunikasi suportif dan iklim komunikasi defensif didapat sebesar $66,33 \%$. Besar nilai persentase tersebut dalam interval kategori, termasuk dalam positif. Sehingga, iklim komunikasi yang ada pada Hotel Best Western Papilio Surabaya bersifat suportif. Skor tersebut membuktikan bahwa enam aspek iklim komunikasi suportif yaitu deskripsi, problem orientation, spontanitas, empati, equality, dan provesionalism memiliki nilai yang tinggi..

Tabel 2. Akumulasi Jawaban Responden tentang Iklim Komunikasi

\begin{tabular}{lllll}
\hline No & & Variabel & Hasil Skor & Kategori \\
\hline & & Iklim komunikasi & & Sangat \\
1. & Iklim & Suportif & $82,82 \%$ & Positif \\
& Komunikasi & Iklim komunikasi & & \\
& & & \\
Total rata- rata skor & defensive & $49,83 \%$ & Negatif \\
Sumber: Data Primer & & $66,33 \%$ & Positif
\end{tabular}

Aspek iklim komunikasi suportif dengan persentase tertinggi sebesar $87,01 \%$ dari keseluruhan pertanyaan mengenai iklim komunikasi adalah aspek provesionalism, bahwa anggota memiliki pemikiran terbuka dan profesional dalam melakukan pekerjaan (Gibb, 1961). Karyawan Hotel Best Western memiliki persepsi bahwa karyawan yang bekerja di Hotel Papilio merupakan karyawan yang memiliki pemikiran terbuka dan bersikap profesional. Di Hotel Best
Western Papilio setiap harinya diadakan evaluasi kerja harian setelah jam kerja berakhir di tiap departemennya (wawancara pra-penelitian 13 April 2019). Pada evaluasi tersebut atasan memberikan saran dan koreksi atas pekerjaan bawahan, dan bawahan juga menyampaikan aspirasinya atas pekerjaan hari itu. Pemikiran terbuka dapat mengembangkan iklim komunikasi yang positif. 
Kemudian pernyataan yang mendapat skor tertinggi kedua adalah pernyataan mengenai aspek problem orientation. Aspek ini diturunkan menjadi dua pertanyaan mengenai pengambilan keputusan berdasarkan diskusi dan kesempatan yang diberikan atasan untuk menyampaikan ide. Kedua item tersebut mendapatkan $85,09 \%$ dan 81,25\%, dimana tergolong dalam kategori sangat positif. Sehingga dapat dikatakan bahwa 104 responden tersebut secara mayoritas berpersepsi sangat setuju terhadap adanya pengambilan keputusan yang berdasarkan diskusi dan tidak ditentukan oleh sepihak saja. Hal ini sesuai dengan pernyataan dari Marcomm Hotel Best Western Papilio Bu Intan, bahwa segala proses pengambilan keputusan terhadap sesuatu selalu didiskusikan terlebih dahulu dengan anggota yang lain (wawanccara prapenelitian, 13 April 2019).

Pertanyaan dengan skor tertinggi ketiga yaitu item pertanyaan mengenai aspek deskriptif yaitu sebesar $84,85 \%$ yang tergolong bersifat sangat positif. Aspek deskriptif dioperasionalisasikan menjadi pertanyaan yang menanyakan tentang apakah karyawan hotel bersikap objektif dan tidak emosional. Hasil tersebut menunjukkan bahwa karyawan yang ada di Hotel Best Western Papilio Surabaya memiliki sifat yang objektif dalam menghadapi segala sesuatu dan tidak emosional. Karyawan yang profesional dalam menjalankan pekerjaaan juga mendorong iklim komunikasi suportif. Karyawan yang bekerja dalam bidang usaha perhotelan dimana termasuk dalam industri hospitality diutamakan keramah- tamahannya (Hermawan, 2018). Sebisa mungkin karyawan selalu tersenyum dan juga ramah terhadap pengunjung. Keramah- tamahan ini dapat muncul jika susasana komunikasi dalam hotel tersebut juga positif. Hal ini sesuai dengan filosofi yang ada di Best Western bahwa karyawan hberusaha secara maksimal untuk memberikan pelayanan terbaik (dokumen pihak Best Western Papilio). Kewajiban tersebut dapat berdampak pada bagaimana karyawan juga bersikap pada rekan kerjanya.

Kemudian untuk aspek equality sendiri merupakan suatu kondisi dimana anggota organisasi tidak saling membedakan dan menganggap semua orang wajib untuk dihargai (Harjana, 2007). Pada hasil penelitian ini aspek equality diturunkan menjadi dua item pertanyaan yaitu karyawan yang saling menghormati tanpa membedabedakan dan kepercayaan sesama karyawan atas kemampuan kerja. Kedua pertanyaan tersebut mendapatkan skor sebesar 82,93\% dan $81,97 \%$, dimana tergolon pada kategori sangat positif. Hal tersebut menandakan bahwa iklim komunikasi suportif di Hotel Best Western Papilio tercipta karena karyawannya yang saling menghormati dam mempercayai satu sama lain. Hal ini karena dalam Hotel Best Western sendiri memiliki value kekeluargaan, dimana antar karyawan juga harus saling mempercayai dan menghormati (wawancara pra-penelitian, 13 April 2019). Kepercayaan terhadap sesama anggota dapat memunculkan iklim yang positif, karena hal itu pertanda bahwa karyawan tidak memandang sebelah mata kemampuan satu sama lain (Istiqomah, 2015).

Aspek selanjutnya dari iklim komunikasi suportif yaitu spontanitas. Responden menanggapi pertanyaan tersebut secara positif dengan hasil skor yaitu $82,69 \%$. Iklim komunikasi yang suportif dapat tercipta jika sesama karyawan juga dekat secara personal tidak hanya dalam pekerjaan (Harjana, 2007). Ketika mereka dekat satu sama lain secara personal, maka tidak aka nada rasa 
takut atu segan untuk saling mengungkapkan sesuatu satu sama lain. Disamping itu juga karyawan dapat secara leluasa menyampaikan pendapatnya. Kenyataan tersebut didukung oleh pernyataan dari $\mathrm{Bu}$ Intan selaku Marcomm Hotel Best Western Papilio bahwa dalam keseharian kerja, bahasa yang digunakan antar rekan kerja lebih ke informal tapi tetap tahu batasan dan saling menghormati (wawancara prapenelitian, 13 April 2019).

Skor persentase terendah yang terdapat pada aspek iklim komunikasi suportif adalah aspek empati yaitu sebesar $77,88 \%$. Skor tersebut masuk dalam kategori positif, yang berarti masih mendapat persetujuan paling banyak, tetapi juga terdapat perbedaan pendapat dari beberapa anggota yang tidak setuju. Empati yang dimaksud dalam skor tersebut adalah mengenai empati atasan terhadap bawahan, dimana atasan bersedia mendengar keluh kesah karyawan tentang perusahaan. Hal ini berarti menunjukkan bahwa beberapa karyawan Hotel Best Western berpendapat bahwa keluhan karyawan tidak didengar. Oleh karena itulah pihak atasan harus lebih memberikan peluang dan kesempatan untuk mendengar karyawannya. Iklim yang suportif ini mendukung karyawan untuk menyampaikan inovasi dan ide yang dimiliki, karyawan bekerjasama dalam menyelesaikan masalah, saling jujur dan peduli satu sama lain, dekat dan tidak takut berkomunikasi datu sama lain dan adanya hak yang sama.

\section{Sistem Penghargaan}

Berdasarkan tabel 2, total skor sistem penghargaan yang didapat adalah $76,6 \%$, dimana hal tersebut menunjukkan bahwa sistem penghargaan yang berlaku di Hotel Best Western Papilio Surabaya baik atau positif. Sistem penghargaan terbagi menjadi dua yaitu sistem penghargaan ektrinsik dan intrinsik. Skor tertinggi diantara pertanyaan penghargaan ekstrinsik adalah sebesar $84,37 \%$. Skor tersebut mengarah pada persetujuan atau kepuasan karyawan terhadap sistem cuti dan hari libur yang diterapkan pada hotel. Karyawan Hotel puas terhadap sistem cuti dan hari libur yang diatur di Hotel Papilio untuk karyawan. Hari libur dan sistem cuti menjadi salah satu penghargaan yang wajib diterima oleh karyawan selain gaji. Bagi karyawan hotel hari libur merupakan suatu hal yang sama pentingnya. Karena berbeda dengan jenis perusahaan yang lain, perhotelan tidak punya hari libur yang rutin dan pasti bagi karyawan sebab hotel tidak tutup pada hari libur (Bustamama et al., 2014).

Tabel 3 Akumulasi Skor Jawaban Responden tentang Sistem Penghargaan

\begin{tabular}{llllllll}
\hline Variabel & \multicolumn{2}{l}{ Jawaban Responden } & & & Jumlah & Hasil & Kategori \\
\hline & STS & TS & S & SS & & \multicolumn{1}{c}{$\begin{array}{c}\text { penilaian } \\
\text { skor }\end{array}$} \\
\hline $\begin{array}{l}\text { Sistem } \\
\begin{array}{l}\text { Penghargaan } \\
\text { Persentase }\end{array}\end{array}$ & 0 & 346 & 2682 & 724 & 3752 & & Positif \\
\hline
\end{tabular}


Kemudian skor terendah dari pertanyaan penghargaan ektrinsik yaitu sebesar $74,27 \%$ mengenai aspek promosi. Sebagian besar karyawan Hotel Best Western Papilio berpendapat bahwa promosi yang berlaku di Hotel Papilio sudah baik, tetapi beberapa karyawan tidak menyetujui hal tersebut. Sistem promosi atau naik jabatan bagi karyawan di Hotel Best Western Papilio ini perlu diperhatikan lebih lagi, beberapa karyawan merasa tidak puas terhadap hal tersebut. Sistem promosi atau naik jabatan bagi karyawan internal terjadi ketika ada karyawan atau atasan yang keluar atau dipindahkan. Karyawan yang naik jabatan diambil dari karyawan yang sebelumnya sudah bekerja di hotel dan tidak mengambil karyawan baru dari luar (wawancara prapenelitian, 20 April 2019).

Kategori penghargaan intrinsik yang masih kurang adalah quality of works, penghargaan di mana atasan memberikan feedback terhadap apa yang telah dikerjakan oleh karyawan dan juga kesempatan dalam menyampaikan ide atau gagasan. Kategori penghargaan tersebut juga dibutuhkan oleh karyawan. Karena dalam bekerja, feedback dari atasan dapat membuat pekerjaan menjadi lebih baik dan memotivasi untuk melakukan pekerjaan lebih baik lagi. Adanya feedback dari atasan merupakan salah satu bentuk perhatian dari atasan terhadp bawahan. Menurut Hertzberg dalam Ong \& Teh (2012) menyatakan bahwa kini orang tidak hanya bekerja hanya untuk dibayar, tapi dukungan dan pengakuan dari atasan merupakan hal penting yang dapat memotivasi anggota organisasi dalam bekerja.

Sistem penghargaan yang diterapkan pada Hotel Papilio secara mayoritas dianggap sudah baik oleh karyawan. Karena sistem penghargaan di Hotel Bset Western Papilio sendiri beragam. Di Hotel Best
Western, berbagai macam penghargaan juga telah diterapkan. Misalkan saja seperti gaji, asuransi kesehatan, award, fasilitas, training, promosi, dan liburan (wawancara prapenelitian, 20 April 2019). Akan tetapi ada beberapa hal yang masih perlu diperhatikan dan diperbaiki agar sistem penghargaan yang diterapkan dapat memuaskan karyawan. Pihak Hotel Papilio perlu memperhatikan lagi mengenai penghargaan instrinsik yang diberikan pada karyawan. Karena pengahargaan intrinsik juga penting bagi karyawan. Hal tersebut antara lain adalah sistem promosi (naik jabatan) yang diterapkan dan feedback dari atasan.

\section{Kinerja}

Kinerja memiliki 8 aspek dalam melakukan pengukuran. Aspek tersebut antara lain produktivitas, kualitas kerja, pengetahuan tentang pekerjaan, adaptasi, inisiatif, kooperatif, pertanggungjawaban, dan kemampuan berkomunikasi. Berdasarkan hasil penilaian responden mengenai 8 aspek kinerja tersebut pada tabel 3 didapatkan skor 75 , 02\%, dimana tergolong positif. Hal tersebut menunjukkan bahwa kinerja karyawan Hotel Best Western Papilio termasuk dalam kategori positif atau baik. Dari 8 aspek tersebut yang memiliki jawaban skor tertinggi menurut karyawan Hotel Best Western Papilio Surabaya adalah produktivitas dengan skor 79,08\%. Produktivitas disini berarti seberapa cepat karyawan dapat menyelesaikan tugasnya dan seberapa mampukah karyawan menentukan prioritas pekerjaan. 
Tabel 3 Akumulasi Skor Jawaban Responden tentang Kinerja

\begin{tabular}{|c|c|c|c|c|c|c|c|c|}
\hline \multirow[t]{2}{*}{ No } & \multirow[t]{2}{*}{ Variabel } & \multicolumn{4}{|c|}{ Jawaban Responden } & \multirow[t]{2}{*}{ Jumlah } & \multirow{2}{*}{$\begin{array}{l}\text { Hasil } \\
\text { penilaian } \\
\text { skor }\end{array}$} & \multirow[t]{2}{*}{ Kategori } \\
\hline & & STS & TS & $\mathbf{S}$ & SS & & & \\
\hline 1. & Kinerja & 0 & 380 & 3537 & 764 & 4681 & \multirow[b]{2}{*}{$75,02 \%$} & \multirow[b]{2}{*}{ Positif } \\
\hline Per & ntase & $0 \%$ & $8,2 \%$ & $75,5 \%$ & $16,3 \%$ & $100 \%$ & & \\
\hline
\end{tabular}

Dilihat dari aspek kualitas kerja dimana kerja dari karyawan sudah sesuai dengan prosedur dan tanpa kesalahan, didapatkan skor $76,20 \%$. Skor tersebut menunjukkan hasil yang positif, yang berarti karyawan Hotel Best Western Papilio secara kualitias kerja tergolong baik. Kualitas kerja termasuk dalam penentuan pengukuran kinerja (Mangkunegara, 2000). Karena pekerjaan karyawan yang memiliki banyak kesalahan dapat menghambat pekerjaan, sehingga kinerja yang dilakukan pun menjadi rendah. Aspek ketiga yaitu pengetahuan tentang pekerjaan. Aspek ini dioperasionalisasikan menjadi dua pertanyaan yang menanyakan tentang pemahaman tugas dan kemampuan menggunakan informasi atau alat saat bekerja. Kedua pertanyaan tersebut mendapatkan skor sebesar 76,20\% dan $76,68 \%$ yang menunjukkan bahwa pengetahuan karyawan Hotel Best Western Papilio tergolong baik. Pengetahuan tentang pekerjaan ini menentukan baik tidaknya suatu pekerjan tersebut dilakukan (Suryariana, 2015). Pengetahuan pekerjaan menunjukkan seberapa paham seorang karyawan akan tugas pekerjaan yang didapatnya dan bagaimana cara karyawan tersebut menyelesaikan.

Aspek yang keempat yaitu adaptasi dan fleksibilitas dimana karyawan mampu untuk menerima instruksi kerja secara cepat dan menyesuaikan dengan cara kerja serta situasi kerja yang ada. Skor yang didapat dari aspek ini adalah $75,72 \%$, di mana tergolong dalam kategori positif. Kecepatan adapatasi seorang karyawan menentukan baik tidaknya kinerja karyawan tersebut. Semakin karyawan mampu membiasakan diri dengan situasi organisasi dan segala tugasnya maka semakin kinerja karyawan tersebut baik (Prawirosentono, 1999). Aspek kelima yaitu inisiatif \& pemecahan masalah dimana menilai tingkat inisiatif selama melaksanakan tugas pekerjaan khususnya dalam hal penanganan masalah-masalah yang timbul. Dalam aspek ini, karyawan Hotel Papilio juga tergolong dalam kategori baik, karena skor yang didapat pada penelitian ini adalah sebesar $74,75 \%$.

Aspek keenam yaitu kooperatif dimana karyawan mampu bekerjasama dalam menyelesaikan pekerjaan. Aspek ini dioperasionalisasikan menjadi dua pertanyaan yaitu atas kemampuan kerjasama dan karyawan yang saling membantu. Dua pertanyaan tersebut mendapatkan skor sebesar $75,48 \%$ dan $73,07 \%$, yang berarti bahwa karyawan mampu bekerjasama satu lain. Kemudian, aspek ketujuh yaitu kemampuan berkomunikasi, dimana menilai apakah mampu untuk berkomunikasi dengan baik secara lisan maupun tulisan. Menurut Tubbs \& Moss dalam Usman (2015), komunikasi dalam organisasi dapat berfungsi sebagai koordinasi sehingga pekerjaan yang dilakukan akan berjalan dengan baik. Aspek ini mendapatkan skor sebesar 73,31, dimana skor tersebut tergolong dalam kategori baik.

Aspek kinerja yang mendapatkan penilaian paling rendah diantara pertanyaan 
mengenai kinerja yang lain adalah pekerjaan, adaptasi, inisiatif, kooperatif, dan pertanggung jawaban. Aspek ini kemampuan berkomunikasi. Hal ini dioperasionalisasikan menjadi dua pertanyaan yaitu menyanyakan mengenai kemandirian dan kehadiran rutin karyawan. Kedua pertanyaan tersebut mendapatkan skor 72,35\%. Meskipun termasuk paling rendah tetapi kategori persentase tersebut masih masuk kategori positif. Pertanggungjawaban yaitu seberapa tepat waktu karyawan datang setiap harinya dan mengikuti aturan. Jika karyawan mampu melaksanakan tanggung jawabnya yaitu mematuhi norma, aturan, dan kebijakan, maka kinerja pun dapat berjalan lancar dan baik (Miftah, 2001). Beberapa karyawan beranggapan bahwa karyawan tidak hadir tepat waktu dan ada beberapa yang melanggar peraturan yang ada.

Selain aspek produktivitas dan tanggung yang memiliki nilai paling rendah diantara item pertanyaan kinerja, aspek lain mengenai kinerja karyawan tergolong baik seperti menunjukkan bahwa untuk meningkatkan kinerja yang lebih baik lagi, tingkat pengawasan dan kedisiplinan karyawan Hotel Best Western Papilio perlu ditingkatkan.

\section{Pengaruh Iklim Komunikasi Organisasi terhadap Kinerja}

Berdasarkan tabel 4 dapat dilihat bahwa nilai t hitung iklim komunikasi 2.115 dan sistem penghargaan 4.156, yang berarti bahwa H0 ditolak, karena t hitung> t tabel, dimana $2.115<1.983>4.156$. Selain itu pula, nilai sig. $\alpha>0,05$, dimana nilai sig. $\alpha$ iklim komunikasi adalah 0,037 dan nilai sig. $\alpha$ sistem penghargaan 0,000 . Dengan demikian, dari hasil perbandingan $t$ tabel dan nilai sig. $\alpha$ dinyatakan $\mathrm{H} 0$ ditolak, yang berarti iklim komunikasi dan sistem penghargaan memiliki pengaruh terhadap kinerja.

kualitas kerja, pengetahuan tentang

Tabel 4 Hasil Uji T

\begin{tabular}{|c|c|c|c|c|c|}
\hline \multirow[b]{2}{*}{ Model } & \multicolumn{2}{|c|}{$\begin{array}{c}\text { Unstandardized } \\
\text { Coefficients }\end{array}$} & \multirow{3}{*}{\begin{tabular}{|c} 
Standardized \\
Coefficients \\
Beta \\
\end{tabular}} & \multirow{3}{*}{$\frac{\mathbf{t}}{3.837}$} & \multirow{3}{*}{$\begin{array}{l}\text { Sig. } \\
.000\end{array}$} \\
\hline & B & Std. Error & & & \\
\hline 1 (Constant) & 17.017 & 4.435 & & & \\
\hline Iklim komunikasi & .319 & .151 & .205 & 2.115 & .037 \\
\hline $\begin{array}{l}\text { Sistem } \\
\text { penghargaan }\end{array}$ & .533 & .128 & .402 & 4.156 & .000 \\
\hline
\end{tabular}

a. Dependent Variable: kinerja

Sumber: Hasil olahan data SPSS 
Tabel 5 Hasil Regresi Linier Sederhana antara X1 dan Y

\begin{tabular}{lr|r|r|r|r}
\multicolumn{2}{c}{$\begin{array}{c}\text { Unstandardized } \\
\text { Coefficients }\end{array}$} & $\begin{array}{c}\text { Standardized } \\
\text { Coefficients }\end{array}$ & & & \\
\hline Model & B & Std. Error & Beta & T & Sig. \\
\hline $1 \quad$ (Constant) & 27.708 & 3.891 & & 7.122 & .000 \\
\hline $\begin{array}{l}\text { Iklim } \\
\text { komunikasi }\end{array}$ & .630 & .141 & .404 & 4.461 & .000 \\
\hline
\end{tabular}

a. Dependent Variable: kinerja

Sumber: Olahan data SPSS

Nilai t hitung dari hasil uji regresi linier didapat sebesar 4,461, yang berarti bahwa $\mathrm{t}$ hitung 4,461> t tabel 1,983. Selain itu pada tabel 3.19 dapat dilihat bahwa nilai sig. $\alpha$ $0,000<0,05$. Kedua hasil tersebut menunjukkan bahwa $\mathrm{H} 0$ pada penelitian ini ditolak dan $\mathrm{H} 1$ diterima. Dengan demikian iklim komunikasi (X1) memiliki pengaruh terhadap kinerja karyawan (Y). sesuai dengan Tabel 5 maka akan terbentuk model persamaan regresi linier sebagai berikut:

$\mathrm{Y}=\alpha+\beta 1 \mathrm{X} 1$

$\mathrm{Y}=27,708+0,630 \mathrm{X} 1$

$\mathrm{Y}$ : Kinerja karyawan

$\alpha$ : Konstanta dari persamaan regresi

$\beta 1$ : Koefisien regresi dari variabel X1, Iklim Komunikasi Organisasi
Pada model persamaan regresi liner sederhana tersebut terlihat bahwa nilai konstanta dari persamaan regresi adalah 27,708, yang berarti bahwa nilai konsisten variabel kinerja karyawan

(Y) akan tetap sebesar 27,708. Koefisien regresi iklim komunikasi adalah sebesar 0,630 . Hal tersebut berarti jika variabel $X$ yaitu iklim komunikasi nilainya bertambah satu, maka nilai variabel $\mathrm{Y}$ akan bertambah sebesar 0,630. Kemudian, besar koefisien tersebut tidak menunjukkan tanda minus, yang berarti bahwa arah hubungan variabel $\mathrm{X} 1$ dan $\mathrm{Y}$ adalah positif. Dimana jika semakin tinggi nilai iklim komunikasi maka semakin tinggi pula nilai kinerja karyawan.

Tabel 6 Pengaruh Iklim Komunikasi terhadap Kinerja

Model Summary

\begin{tabular}{|c|c|c|c|c|}
\hline Model & $\mathbf{R}$ & R Square & $\begin{array}{c}\text { Adjusted R } \\
\text { Square }\end{array}$ & $\begin{array}{l}\text { Std. Error of } \\
\text { the Estimate }\end{array}$ \\
\hline 1 & $.404^{\mathrm{a}}$ & .265 & .155 & 3.14922 \\
\hline
\end{tabular}

Besarnya nilai pengaruh varibel iklim komunikasi organisasi (X1) terhadap Kinerja (Y) dapat dilihat kolom R square. Kolom R pada hasil menunjukan koefisien korelasi. Pada penelitian ini koefisien korelasi antara iklim komunikasi organisasi dan kinerja adalah sebesar 0,404. Sedangkan untuk besarnya nilai pengaruh iklim komunikasi (X1) terhadap kinerja (Y) adalah 0,265 atau setara 26,5\%. Iklim komunikasi mempengaruhi kinerja sebesar $26,5 \%$ dan $73,5 \%$ lainnya 
dipengaruhi oleh faktor- faktor lain. Stern dalam Mangkunegara (2010, pp.16- 17) terdapat dua faktor yang dapat menjadi penentu dalam kinerja individu yaitu faktor individu dan faktor lingkungan kerja organisasi. Faktor individu disini termasuk kemampuan, kecerdasan, emosi, pengetahuan, motivasi, dan konsentrasi. Sedangkan faktor lingkungan kerja yang dimaksud adalah uraian jabatan yang jelas, penghargaan/ insentif, target kerja, pola komunikasi kerja efektif, hubungan kerja harmonis, peluang berkarier, dan fasilitas kerja yang relatif dan kepemimpinan.

\section{Pengaruh Sistem Penghargaan terhadap Kinerja}

Berdasarkan dari tabel 7, nilai t hitung yang didapat adalah sebesar 5,890, yang berarti bahwa t hitung 5,890 > t tabel 1,983.

Tabel 7 Hasil Regresi Linier Sederhana antara X2 dan Y

\begin{tabular}{|c|c|c|c|c|c|}
\hline Model & $\begin{array}{r}\text { Unstanc } \\
\text { Coeff } \\
\text { B } \\
\end{array}$ & $\begin{array}{l}\text { ardized } \\
\text { cients } \\
\text { Std. } \\
\text { Error } \\
\end{array}$ & $\begin{array}{c}\text { Standardized } \\
\text { Coefficients } \\
\text { Beta } \\
\end{array}$ & $\mathbf{T}$ & Sig. \\
\hline $1 \quad$ (Constant) & 20.941 & 4.097 & & 5.112 & .000 \\
\hline $\begin{array}{l}\text { sistem } \\
\text { penghargaan }\end{array}$ & .667 & .113 & .504 & 5.890 & .000 \\
\hline
\end{tabular}

a. Dependent Variable: kinerja

Sumber: Olahan data SPSS

Selain itu pada tabel 7 dapat dilihat bahwa nilai sig. $\alpha \quad 0,000<0,05$. Hal tersebut menunjukkan bahwa $\mathrm{H} 0$ pada penelitian ini ditolak dan H2 diterima. Dengan demikian sistem penghargaan (X2) memiliki pengaruh terhadap kinerja karyawan (Y). Sesuai hasil dari tabel 3.22 maka akan terbentuk model persamaan regresi linier sebagai berikut:

$\mathrm{Y}=\alpha+\beta 1 \mathrm{X} 2$

$\mathrm{Y}=20,941+0,667 \mathrm{X} 2$

$\mathrm{Y}$ : Kinerja karyawan

$\alpha$ : Konstanta dari persamaan regresi

$\beta 2$ : Koefisien regresi dari variabel X2, Sistem Penghargaan

Model persamaan regresi liner sederhana tersebut menunjukkan bahwa nilai konstanta dari persamaan regresi adalah 20,941, yang berarti bahwa nilai konsisten variabel kinerja karyawan
(Y) akan tetap sebesar 20,941. Koefisien regresi sistem penghargaan pada persamaan regresi linier tersebut adalah sebesar 0,667. Hal tersebut berarti jika variabel $X$ yaitu sistem penghargaan nilainya bertambah satu, maka nilai variabel $\mathrm{Y}$ akan bertambah sebesar 0,667. Kemudian, besar koefisien regresi sistem penghargaan yang sebesar $+0,667$, menunjukkan arah hubungan positif antara variabel X2. Jika semakin tinggi nilai sistem penghargaan, maka semakin tinggi pula nilai kinerja karyawan. Hasil tersebut sejalan dengan teori yang berkaitan dengan aspek-aspek sistem penghargaan. Sistem penghargaan sendiri terbagi menjadi dua yaitu penghargaan intrinsik dan penghargaan ektrinsik. Penghargaan ektrinsik terdiri dari dari upah/ gaji, bonus/komisi, promosi dan benefit (tunjangan). Penghargaan ektrinsik ini dapat meningkatkan kinerja dari karyawan, karena memang menjadi tujuan 
utama seorang karyawan melakukan dan meningkatkan kerja karena pengakuan pekerjaan (Bohlander \& Snell, 2004). atasan. Ketidakefektivitasan pemilihan Adanya penghargaan ekstrinsik ini sistem penghargaan yang digunakan digunakan untuk memenuhi kebutuhan dari karyawan. Sehingga karyawan termotivasi untuk melakukan kinerja yang lebih baik jika penghargaan ekstrinsik baik juga.

Setiap karyawan memiliki kebutuhan dan motivator masing- masing. Ada karyawan yang semangat bila mendapat bonus, ada juga karyawan yang semangat organisasi akan mempengaruhi kepuasan dan menurunkan kinerja mereka (Bustamama et al., 2014). Oleh karena itulah penghargaan intrinsik yang terdiri dari inspiration \& values; quality of works; interest \& choices; \& environment juga dapat mempengaruhi kinerja karyawan.

Tabel 8 Hasil Besarnya Pengaruh Sistem Penghargaan terhadap Kinerja

\begin{tabular}{cc|c|c|c}
\hline Model & R & R Square & $\begin{array}{c}\text { Adjusted R } \\
\text { Square }\end{array}$ & $\begin{array}{c}\text { Std. Error of } \\
\text { the Estimate }\end{array}$ \\
\hline 1 & $.504^{\mathrm{a}}$ & .324 & .316 & 2.97399 \\
\hline
\end{tabular}

a. Predictors: (Constant), sistem penghargaan

Sumber: Olahan data SPSS

Besarnya nilai pengaruh varibel sistem penghargaan (X2) terhadap Kinerja (Y) dapat dilihat pada kolom $\mathrm{R}$ square. Kolom R pada hasil menunjukan koefisien korelasi sistem penghargaan sebesar 0,504. Kemudian, untuk besarnya nilai pengaruh sisitem penghargaan (X2) terhadap kinerja (Y) adalah 0,324 atau setara $32,4 \%$ dan $67,6 \%$ lainnya dipengaruhi oleh faktor- faktor lain. Berdasarkan Wibowo (2007), kinerja karyawan dapat dipengaruhi oleh beberapa faktor antara lain ketersediaan fasilitas, lingkungan kerja, tanggung jawab kerja, motivasi, budaya organisasi, komunikasi, kepemimpinan, insentif, dan pelatihan.

\section{Pengaruh Iklim Komunikasi Organisasi \& Sistem Penghargaan terhadap Kinerja}

Berdasarkan tabel 9, dapat dilihat bahwa nilai $\mathrm{f}$ hitung yang didapat dari data sebesar 20,175. Hal tersebut menunjukkan bahwa nilai f hitung lebih besar dari $\mathrm{f}$ tabel yang nilainya 3,09 .

Tabel 9 Hasil Uji F

\begin{tabular}{|c|c|c|c|c|c|c|}
\hline \multicolumn{2}{|c|}{ Model } & \multirow{2}{*}{$\begin{array}{c}\text { Sum of } \\
\text { Squares } \\
\mathbf{3 4 5 . 1 1 6} \\
\end{array}$} & \multirow{2}{*}{$\begin{array}{l}\text { df } \\
\quad 2 \\
\end{array}$} & \multirow{2}{*}{$\begin{array}{l}\text { Mean } \\
\text { Square } \\
172.558\end{array}$} & \multirow{2}{*}{$\begin{array}{c}F \\
20.175\end{array}$} & \multirow{2}{*}{$\begin{array}{l}\text { Sig. } \\
.000^{b}\end{array}$} \\
\hline 1 & Regression & & & & & \\
\hline & Residual & 863.875 & 101 & 8.553 & & \\
\hline & Total & 1208.990 & 103 & & & \\
\hline
\end{tabular}

Selain itu pula nilai sig. $\alpha$ menunjukkan 0,000 yang berarti sig $\alpha<0,05$. Dengan demikian dapat disimpulkan bahwa $\mathrm{HO}$ ditolak dan H3 diterima, dimana iklim komunikasi dan sistem penghargaan secara simultan berpengaruh pada kinerja. 
$\mathrm{Y}=17,017+0,319 \mathrm{X} 1+0,533 \mathrm{X} 2$

Persamaan regresi linier berganda tersebut memiliki interpretasi data tersendiri. Nilai konstanta sebesar 17, 017 memiliki arti bahwa nilai konsisten variabel kinerja karyawan (Y) akan tetap sebesar 17,017. Kemudian nilai 0,319 pada variabel iklim komunikasi organisasi dan nilai 0,533 pada variabel sistem penghargaan menunjukkan bahwa setiap penambahan nilai 1 pada $X$ maka akan nilai $\mathrm{Y}$ akan bertambah sesuai nilai persamaan tersebut. Nilai $+0,316$ dan $+0,533$ menunjukkan bahwa arah hubungan positif. Jika variabel iklim komunikasi dan sistem penghargaan naik maka kinerja juga akan naik.

Tabel 10 Hasil Uji Koefisien Determinasi

\begin{tabular}{lr|r|r|r|r}
\hline Model & \multicolumn{1}{l|}{ R } & R Square & \multicolumn{1}{c}{$\begin{array}{c}\text { Adjusted R } \\
\text { Square }\end{array}$} & $\begin{array}{c}\text { Std. Error of the } \\
\text { Estimate }\end{array}$ \\
\hline 1 & $.534^{\mathrm{a}}$ & .302 & .294 & 2.92459 \\
\hline
\end{tabular}

a. Predictors: (Constant), penghargaan, iklim komunikasi

Sumber: Olahan Data SPSS

Dari tabel 10 tersebut dapat dilihat pada kolom $R$ Square bahwa nilai koefisien determinasi sebesar 0,302 atau setara 30,2\%. Hal tersebut berarti bahawa secara simultan iklim komunikasi (X1) dan sistem penghargaan (X2) memiliki pengaruh terhadap kinerja karyawan (Y) yaitu sebesar $30,2 \%$ dan sisanya yaitu $69,8 \%$ dipengaruhi oleh faktor lain yang tidak diteliti dalam penelitian ini.

Berdasarkan Mangkunegara (2010, pp.16- 17) faktor yang dapat menjadi penentu dalam kinerja individu yaitu faktor individu dan faktor lingkungan kerja organisasi. Faktor individu disini termasuk kemampuan, kecerdasan, emosi, pengetahuan, motivasi, dan konsentrasi. Sedangkan faktor lingkungan kerja yang dimaksud adalah target kerja, pola komunikasi kerja efektif, hubungan kerja harmonis, peluang berkarier, fasilitas kerja, pemimpin yang memberdayakan, dan bagaimana pemimpin memberikan penghargaan (Wibowo, 2007, p. 76).

Selain pernyataan dari mangkunegara tersebut Setiyawan dan Waridin (2006, p.184) juga mengelompokkan faktor yang dapat mempengaruhi kinerja menjadi tiga, sebagai berikut:

1. Faktor individual yang terdiri dari : kemampuan dan keahlian, latar belakang, demografi, motiyasi kerja dan disiplin kerja.

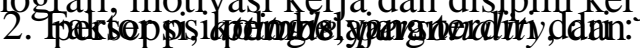
3. Faktor organisasi yang terdiri dari : sistem atau bentuk organisasi sumber daya, kepemimpinan, komunikasi, lingkungan kerja, budaya kerja, budaya organisasi, penghargaan, struktur, diklat dan job design.

\section{SIMPULAN}

Berdasarkan hasil temuan dan analisis data diperoleh kesimpulan bahwa terdapat pengaruh antara iklim komunikasi organisasi dan sistem penghargaan terhadap kinerja karyawan Hotel Best Western Papilio Surabaya. Besarnya pengaruh iklim komunikasi dan sistem penghargaan secara bersama- sama terhadap kinerja karyawan dihasilkan dari uji koefisien determinasi sebesar 30,2\% dan sisanya yaitu 69,8\% dipengaruhi oleh faktor lain yang tidak diteliti dalam penelitian ini. Temuan lain yang bisa didapatkan pada penelitian ini menunjukkan bahwa iklim komunikasi yang ada di Hotel Best Western Papilio adalah 
suportif. Sedangkan sistem penghargaan yang ada di Hotel Best Western Papilio Surabaya hasilnya menurut responden adalah positif atau baik. Selain itu kinerja karyawan Hotel Best Western Papilio Surabaya dilihat dari hasil responden adalah positif.

Temuan lain yang didapat dari penelitian ini adalah secara parsial yaitu iklim komunikasi memiliki pengaruh terhadap kinerja dan sistem penghargaan memiliki berpengaruh kinerja. Hal tersebut menunjukkan semakin iklim komunikasi positif semakin positif pula kinerja karyawan. Besarnya pengaruh iklim komunikasi terhadap kinerja karyawan adalah sebesar $26,5 \%$ dan $73,5 \%$ lainnya dipengaruhi oleh faktor- faktor lain. Kemudian, sistem penghargaan memiliki pengaruh terhadap kinerja, besarnya nilai pengaruh sistem penghargaan terhadap kinerja karyawan adalah sebesar $32,4 \%$ dan $67,6 \%$ lainnya dipengaruhi oleh faktorfaktor lain.

Berdasarkan hasil penelitian yang diperoleh, maka saran yang dapat dibagikan kepada pihak Hotel Best Western Papilio Surabaya adalah lebih mendekatkan anggota organisasi satu sama lain dan juga lebih membuka lebar kesempatan dan mendengarkan keluhan dari karyawan tentang perusahaan. Selain itu, pihak Hotel juga perlu mempertimbangkan dan memperhatikan mengenai sistem promosi yang diterapkan dan atasan meningkatkan feedback yang diberikan untuk karyawan. Untuk itu maka diperlukan bagi pihak hotel papilio untuk melakukan perbaikan pada aspek iklim komunikasi dan sistem penghargaan tersebut dalam rangka meningkatkan kinerja karyawana menjadi lebih baik lagi.

Kemudian untuk penelitian selanjutnya mengenai iklim komunikasi organisasi, peneliti menganjurkan untuk menambah data kualitatif agar analisis menjadi mendalam. Penelitian selanjutnya juga dapat dilakukan dengan menggunakan metode atau pendekatan yang berbeda yaitu dengan menggunakan pendekatan penelitian kualitatif dengan menggunakan tokoh yang berbeda sebagai referensi sehingga pembahasan mengenai aspek iklim komunikasi organisasi semakin meluas dan beragam. Peneliti juga menganjurkan untuk penelitian selanjutnya bisa meneliti faktor lain yang bisa dipengaruhi oleh iklim komunikasi organisasi selain kinerja.

\section{REFERENSI}

Armstrong, M. (2003). Employee reward (3rd ed.).London :CIPD.

Armstrong, M.,\&Murlis,H.(2007).Reward management: a handbook of remuneration strategy and practice $\left(5^{\text {th }}\right.$ ed.). USA: Kogan page.

Bartono, P. H., \& Ruffino, E. M. (2007). Hotel communication management. Yogyakarta: Andi Offset.

Beer, M., \& Spector, B. (1985). Readings in human resource management. New York: The Free press a division of Macmillan, Inc.

Bohlander, G., \& Snell, S. (2004). Managing human resources. South Western: Thompson Corporation.

Byars, L. L., \& Rue, L. (2000). Human resource management. USA: McGrawHill Companies Inc.

Damardjati, R. S. (2001). Istilah-istilah dunia pariwisata. Jakarta: Pradnya Paramita.

Deetz, S. (2001).Conceptual foundations. In M. Jablin \& L. Putnam, The New Handbook of Organizational 
Communication (pp. 3- 46). California: Sage publication Inc.

Eisenberg, E. M., \& Goodall, H. L. (1997). Organizational communication: balancing creativity and constraint $\left(2^{\text {nd }}\right.$ ed. $)$. New York: St. Martin's Press.

Ghozali, I. (2011). Aplikasi analisis multivariate dengan program SPSS. Semarang: BP Universitas Diponegoro.

Handoko,T.H.(2008). Manajemen personalia dan sumberdaya manusia. Yogyakarta: BPFE.

Hermawan, H., Brahmanto, E., \& Hamzah, F. (2018). Pengantar manajemen hospitality. Pemalang: PT Nasya Expanding Management.

Ismayanti. (2010). Pengantar pariwisata. Jakarta: PT Gramedia.

Kriyantono, R. (2006). Riset komunikasi: disertai contoh praktis riset media, public relation, advertising, komunikasi organisasi, komunikasi pemasaran. Jakarta: Kencana Prenada Media Grup.

Mangkunegara, A. A. A. (2000). Manajemen sumber daya manusia perusahaan. Bandung: PT Remaja Rosdakarya.

Mangkunegara, A. A. A. (2010). Evaluasi kinerja SDM. Bandung: PT Refika Aditama.

Miller, K. (2015). Organizational communication: approaches and processes $\left(6^{\text {th }}\right.$ ed.). USA: Wadsworth Cengage Learning.

Mulyana D. (2007).Ilmu komunikasi suatu pengantar. Bandung: PT Rosdakarya.

Pace, W. R., \& Faules, D. (2015).Komunikasi organisasi strategi meningkatkan kinerja perusahaan. Bandung: PT Remaja Rosdakarya Offset.
Purwanto, D. (2006). Komunikasi Bisnis. Jakarta: Erlangga.

Prawirosentono, S. (1999). Kebijakan kinerja karyawan. Yogyakarta: BPFE.

Richmond, V. O., McCroskey, J. C., \& McCroskey, L. L (2005).

Organizational communication for survival. USA: Pearson education.

Umar, H. (2002). Metode risetkomunikasi organisasi. Jakarta: PT Gramedia Pustaka Utama.

Wibowo. (2007). Manajemen kinerja. Jakarta: PT Raja Grafindo Persada.

Bustamama, F. L., Tenga, S. S., \& Abdullah F. Z. (2014). Reward management and job satisfaction among frontline employees in hotel industry in Malaysia .Procedia - Social and Behavioral Sciences 144, pp.392 - 402.

Fay, C. H.,\& Thompson M. A.(2001). Contextual determinants of reward systems' success: an exploratory study.Human Resource Management, 40 (3), pp.213-226.

Forward, G. L., Czech, K., \& Lee, M. C. (2011). Assessing gibb's supportive and defensive communication climate: an examination of measurement and construct validity. Communication Research Report Routledge, 28 (1), pp.1-15.

Gibb, J. (1961). Defensive communication. Journal of Communication, 11, pp.141- 48. Harjana, A. A. (2007). Iklim Komunikasi Keorganisasian. Jurnal Ilmu Komunikasi, Vol. 4(2), pp.179- 231.

Mehmood, S, Ramzan, M, \& Akbar, MT. (2013). Managing Performance through Reward. Iosr journals, Vol. 15 (2), pp. 64-67. 
Ong, T.S., \& The, B.H. (2012). Reward system and performance within malaysian manufacturing companies.

World applied Sciences Journal, Vol.19 (7), pp.1009- 10017.

Best Western Papilio Surabaya Raih Sertifikasi Bintang Empat. (2016, Desember). Dailyhotels.id article. Retrieved from https://dailyhotels.id/2016/12/bestwestern-papilio-surabaya-raihsertifikasi-bintang-empat/

Rozack, A. (2017, August 25).

Perkembangan hotel di surabaya terlalu over. Jawa Pos Radar Surabaya.

Retrieved from https://radar.jawapos.com/radarsurabay a/read/2017/08/25/9553/perkembangan -hotel-di-surabaya-terlalu-over

\section{BIODATA PENULIS}

Hardikna Agasta, Bachelor of Communication Science Airlangga University, Surabaya, Indonesia.

Telepon: 085330340334

Id line: diknaagasta 